\title{
RAZÃO DE MORTALIDADE PROPORCIONAL DE SWAROOP E UEMURA NECESSIDADE DE REVISÃO PERIÓDICA DE SUA DEFINIÇÃO *
}

\author{
SWAROOP AND UEMURA 'S PROPORTIONAL MORTALITY RATIO
}

THE NEED FOR PERIODIC REVISION OF THE DEFINITION *

\author{
Elias Rodrigues de Paiva * \\ Yára Juliano ** \\ Neil Ferreira Novo * \\ Walter Leser *
}

\begin{abstract}
PAIVA, E.R. de et al. Razão de mortalidade proporcional de Swaroop e Uemura. Necessidade de revisão periódica de sua definiç̧ão. Rev.Saúde públ., S.Paulo, 21 : 90-107, 1987.

RESUMO: Utilizando dados referentes a 34 países, em quatro épocas, $1950,1960,1970$ e 1980 , foi verificado que a percentagem de óbitos com 50 anos e mais, que constitui a Razão de Mortalidade Proporcional, indicador de nível de saúde de populações proposta por Swarrop e Uemura, não proporcionou 0 maior poder de discriminação entre países mais e menos desenvolvidos, em qualquer das épocas; nas duas últimas, foi a percentagem de óbitos com 75 anos e mais que correspondeu esse major poder. Verificou-se ainda que os deslocamentos de óbitos para faixas etárias mais elevadas, durante um determinado período, foram também mais bem traduzidas pelas variações no mesmo período, dessa percentagem, sendo útil a complementação dessas informaçōes pelas variaçōes da percentagem de óbitos com 65 anos e mais. É sugerida a conveniência de reformulação das classes propostas por Swaroop e Uemura, definindo-se outras baseadas na RMP dada por 75 anos e mais, com os seguintes limites: $0 \longmapsto 20,20 \curvearrowleft 40,40 \curvearrowleft 50,50 \Vdash 55$ e 55 ou mais, com previsão de desdobramento futuro da última.
\end{abstract}

UNITERMOS: Indicadores de saúde. Mortalidade.

\section{INTRODUÇÃO}

A maioria dos indicadores de nivel da saúde baseiase em dados de mortalidade. Um desses indicadores, a Razão de Mortalidade Proporcional (RMP), foi proposto por Swaroop e Uemura ${ }^{13}$, em 1957; compararam dois grupos de países que classificavam como "desenvolvidos" e "subdesenvolvidos", calculando, pela técnica da função discriminante linear, os valores da distância quadrática generalizada de Mahalanobis $\left(D^{2}\right)$ (Mahalanobis $\left.{ }^{10}, 1936\right)$ referentes as percentagens de óbitos contadas a partir de cada um dos limites dos grupos etários usuais. Verifica. ram, assim, que o maior valor de $D^{2}$ era obtido quando a percentagem de óbitos correspondia ao grupo de 50 anos ou mais. Mesmo isoladamente ou em combinações, outros indicadores (Coeficiente de Mortalidade Infantil, Esperança de Vida e Coeficiente de Mortalidade Geral Bruto) não forneciam valores maiores.

Entre as inúmeras vantagens enumeradas por aqueles autores, para o seu indicador, destaca-se a que $\mathrm{diz}$ respeito à "disponibilidade de dados, relativos a um grande número de países, em base regular".

\section{INTRODUCTION}

The majority of health level indicators is based on mortality data. One of these indicators, the Proportional Mortality Ratio (PMR), was proposed by Swaroop and Uemura ${ }^{13}$ in 1957. They compared two groups of countries which they classified as "developed" and "under-developed", calculating, by the linear discriminating function technique, Mahalanobis's10 (1936) generalized quadratic distance values $\left(D^{2}\right)$ with reference to the percentages of deaths counted as from each one of the limits of the normal age groups. They thus discovered that the greatest value of $D^{2}$ was obtained when the percentage of deaths corresponded to the group of 50 and above. Neither isolatedly nor in combination did other indicators (Coefficient of Infant Mortality, Life Expectancy and Coefficient of Crude General Mortality) provide higher values.

Among the innumerable advantages advanced by these authors, in favor of their indicator, one may emphasize that which relates to the "availability of data, related to a large number of countries, on a regular basis."

* Resumo da tese de doutorado, apresentada à Escola Paulista de Medicina por Elias Rodrigues Paiva, em 1981, subordinada ao mesmo título.

Dissertation sinopsis presented at the "Escola Paulista de Medicina", by Elias Rodrigues Paiva, with the same title, in 1981.

- Departamento de Medicina Preventiva da Escola Paulista de Medicina. Rua Botucatu, 740 - 04023 - São Paulo, SP - Brasil. 
PAIVA, E.R. de et al. Razão de mortalidade proporcional de Swaroop e Uemura. Necessidade de revisão periódica de sua definição. Rev.Saúde públ., S.Paulo, 21 : 90-107, 1987.

E sabido que, decorridos praticamente 30 anos desde a época da proposta desse indicador, melhorias acentuadas no nível de saúde devem ter sido apresentadas pela maioria dos países, refletindo-se evidentemente na mortalidade.

Entre os muitos fatores que devem ter contribuído para esta melhoria podem ser lembrados o saneamento básico, a expansão do emprego de inseticidas de ação residual, de quimioterápicos e de antibióticos, bem como a maior extensão de serviços de assistência médico-sanitária $e$, de forma geral, progressos quanto às condições de vida das populaçōes.

E provável que alguns fatores contrários possam também ter interferido, principalmente nos paises do terceiro mundo, mas, um balanço geral deve apontar resultado favorável.

Pareceu haver, então, fundamentação suficiente para a formulação de hipóteses quanto às conseqüências, na mortalidade proporcional por idades, dessa evolução do nivel de saúde:

I - os valores da RMP em épocas sucessivas, a partir de 1950 , em cada país, mostraram tendência a crescer;

II - o grupo etário definido por Swaroop e Uemura, o de 50 anos ou mais de idade, não continuou a ser o que apresenta o maior poder de discriminação que, em épocas sucessivas, deslocou-se para idades mais elevadas;

III - a ordenação dos países em classes, proposta por Swaroop e Uemura, baseada nesse grupo etário, deixou de descrever, expressivamente, a posição relativa dos mesmos, em termos de nível de saúde.

Além disso, a confirmação da hipótese I implicaria a transferência progressiva de óbitos, dos grupos etários com menos de 50 anos para o de 50 anos ou mais. Nos países em que, no início de um período, o nivel de saúde era precário, expresso por pequeno valor da RMP, o grau de melhoria alcançado durante o período estudado corresponderia ao volume de tais transferências. Sendo grande, no início, o contingente de óbitos com menos de 50 anos, melhorias acentuadas encontrariam expressão em elevações substanciais da RMP.

Em contraposição, em países com alto nível de saúde, a parcela dos óbitos com menos de 50 anos já é, de início, pequena, reduzindo a possibilidade de transferências, durante o período estudado, para o grupo que define a RMP. Como consequiência, mesmo que ainda ocorresse melhoria acentuada do nivel de saúde, eventualmente evidenciável por outros indicadores, seria de pouca monta a repercussão no acréscimo do valor da RMP. É admissivel que, em tal caso, as transferências tenham ocorrido den-
It is well known that, after the passage of practically thirty years since the date of the proposal of this indicator, considerable improvements in the health level of the majority of countries have become apparent - and this has been clearly reflected, in the mortality rates.

Among the many factors which must have contributed to this improvement, basic sanitation, the expansion of the use of insecticides with residual action, and of chemotherapeutical and antibiotic substances, as well as the greater extension of the services of medico-sanitary care, and in a general way the progress with regard to the living standards of the populations, may be recorded.

It is probable that some adverse factors may also be infered, mainly in Third-World countries, but a general assessment should show a favorable result.

It seemed to us therefore that there was a sufficient foundation for the formulation of certain hypotheses as to the consequences, in terms of the proportional mortality by age, of this evolution of the health level:

I - the values of the PMR for successive periods, as from 1950, for each country, have shown a tendency to increase;

II - the age group defined by Swaroop and Uemura, that of 50 years of age and above, has not continued to be that which has shown the greatest power of discimination - which, in successive periods, has moved to older age groups;

III - the ordering of the countries into classes, proposed by Swaroop and Uemura ${ }^{13}$, based on that age-group, has ceased to describe, significantly, their relative positions, in terms of health levels.

Beyong this, the confirmation of hypothesis I would mean the progressive transfer of deaths from the age groups of less than 50 years of age to those with 50 years of age and obove. In those countries in which, at the beginning of a period, the level of health was low, expressed as a low PMR value, the degree of improvement achieved during the period under study would correspond to the volume of such transfers. If the value of the contingent of deaths below 50 years of age at the beginning of the period was high, notable improvements would express themselves in substantial increases of the PMR.

In contradistinction, in countries with high health levels, the number of deaths at less than 50 years of age is already small at the beginning of the period, thus diminishing the possibility of such transfers, during the period under study, to that group which defines the PMR. As a result, even though there 
PAIVA, E.R. de et al. Swaroop and Uemura's proportional mortality ratio. The need periodic revision of the definition. Rev. Saúde públ., S.Paulo, 21 : 90-107, 1987.

tro do grupo etário de 50 anos ou mais, com deslocamento da mortalidade proporcional para as faixas de idade mais elevadas que nele se incluem.

Com base nesse raciocínio, pareceu cabível formular a hipótese IV, condicionada à confirmação da hipótese I:

IV - considerando-se subgrupos etários resultantes da divisão do definido por Swaroop e Uemu$\mathrm{ra}^{13}$, o deslocamento da mortalidade proporcional, de uma época para outra, no sentido das idades mais elevadas, não será traduzido, adequadamente, pelas variações da RMP como proposta por Swaroop e Uemura, sendo-o, entretanto, quando adotado outro limite de idade, maior, para a definição dessa razâo.

Com o objetivo de por a prova essas hipóteses, foi estudada a mortalidade proporcional por idades em um grupo de países para os quais se dispusesse de dados confiáveis, a intervalos de cerca de 10 anos, a partir de 1950, até 1980.

\section{MATERIAL E METTODOS}

\section{Dados Básicos}

Tendo em conta as hipóteses formuladas, o plano de trabalho previu o estudo de dados de mortalidade, segundo grupos etários, de países para os quais pudessem ser coligidos para 1950, 1960, 1970 e 1980. Admitiu-se que, quando ñ̃o estivessem disponíveis para essas datas, seriam utilizados os referentes a anos com afastamento não maior do que três, com uma única exceção no caso de $1950 \mathrm{em}$ que, para quatro países, foi necessário aceitar afastamentos de quatro anos.

Assim, para que um país fosse incluído no estudo, era necessário que se dispusesse de dados para as quatro épocas e que a distribuição dos óbitos, por idades, se fizesse por classes iguais às adotadas por Swaroop e Uemura ${ }^{13}$. Assim foi possível a obtenção de dados confiáveis para 34 países, em ediçбes do Demographic Yearbook ${ }^{1-5}(1950,1951,1960,1970$ e 1981). Como se tornou interessante o estudo apenas da última época, 1980 , pôde-se elevar esse número para 66.

Os estudos a serem desenvolvidos visavam a:

1 - observar a evolução dos valores da RMP, a partir de 1950, em cada país;

2 - calcular o poder de discriminação, medido pela distância quadrática generalizada $\left(D^{2}\right)$ de Maha. lanobis ${ }^{10}$, das percentagens acumuladas de óbi. tos até o limite superior de cada grupo etário, segundo o modelo empregado por Swaroop e Uemura; were to occur a notable improvement in the health levels, as occasionally evidenced by other indicators, the repercussion in the increase of the PMR value would be very small. It is to be admitted that, in such a case, the transfers will have occurred within the 50 or above age group, with a displacement of proportional mortality to those higher age groups included within it.

Based on this reasoning, it seemed reasonable to formulate hypothesis IV, dependent on the confirmation of hypothesis I:

IV - if the age subgroups resulting from the division of that proposed by Swaroop and Uemura ${ }^{13}$ are considered, the displacement of proportional mortality towards greater age, from one period to another, will not be adequately translated by the variations of the PMR as proposed by Swaroop and Uemura - however, they would be so translated were another, higher, age-limit adopted for the definiton of this rate.

It was decided that proportional mortality by age for a group of countries from which trustworthy data were available, at ten-year intervals from 1950 up to 1980 , should be studied with a view to putting this hypothesis to the test.

\section{MATERIAL AND METHODS}

\section{Basic Data}

Bearing in mind the hypotheses formulated, the plan of work proposed the study of mortality data, by age group, for countries from which data were available for $1950,1960,1970$ and 1980 . It was allowed that, should data for these dates not be available, use would be made of those with not more than three years of difference, with the one exception made in relation to 1950-in which case, for four countries, it was necessary to accept distances of four years.

Thus, so that a country should be included in the study, it was necessary that data for all the four periods should be available and that the distribution of deaths by age should have been made in accord with groups equal to those adopted by Swaroop and Uemura. In this way it was possible to obtain trustworthy data for 34 countries from editions of the Demographic Yearbook ${ }^{1-5}$ (1950, 1951, 1960, 1970 and 1980). As will be seen, when the study of the last period only was considered, i.e. 1980 , this number rose to 66 .

The studies to be undertaken sought to:

1. observe the evolution of the PMR values, as from 1950, for each country; 
PAIVA, E.R. de et al. Razão de mortalidade proporcional de Swaroop e Uemura. Necessidade de revisão periódica de sua defínição. Rev. Saúde públ., S.Paulo, 21 : 90-107, 1987.

3 - verificar o comportamento, em caua época, da distribuiçāo dos paises pelas classes propostas por Swaroop e Uemura ${ }^{13}$;

4 - em função dos resultados obtidos, examinar a conveniência de modificação das definições, tanto da razão de mortalidade proporcional quando das classes baseadas em seu valor.

\section{Formação dos Grupos}

Para a formação dos grupos a serem comparados mediante o cálculo da função discriminante linear, preferiu-se usar um critério mais objetivo do que o usado por Swaroop e Uemura que classificaram países como "desenvolvidos" e "subdesenvolvidos" pelo que, "a priori", deles sabiam. Recorreu-se a um indicador de nivel de saúde que, nos termos da variável que o traduz, permite a ordenação dos países estudados, e que para o seu cálculo envolve valores da mortalidade proporcional por grupos de idade; o indicador em causa é o quantificado de Guedes (IG) (Guedes? , 1972).

Para determinar o tamanho dos grupos a serem comparados, adotou-se o critério proposto por Kelley ${ }^{9}$ (1939) para formação de grupos em análises por itens de testes educacionais; segundo esse autor, a maior discriminação entre os grupos é alcan. çada quando cada um deles, em uma e outra das extremidades da ordenação do resultado global do teste, inclui $27 \%$ do total de observações. No presente caso, essa percentagem corresponde, por aproximação ao inteiro, a 9 países.

Assim, o grupo de países, designado por "menos desenvolvidos", incluiu os que ocupam, na ordenação do IG, os postos de 1 a 9 , enquanto os considerados "mais desenvolvidos" ocupam os postos de 26 a 34 .

A composição dos grupos variou, de época para época, em função das diferenças na evolução mostrada pelos países, em termos de IG.

$\mathrm{Na}$ Tabela 1 são apresentados os grupos de países que, em cada época, foram comparados, incluindose também o ano a que os dados dizem respeito.

No ano de 1980 , além do estudo referente aos 34 países focalizados nas quatro épocas, foi realizado outro abrangendo 66 países. Com o critério já referido, cada grupo passou, neste caso, a incluir 18 países.

\section{Métodos Estatísticos}

\section{Função discriminante linear}

O poder de discriminação, entre os grupos, proporcionado pelas diferenças entre as percentagens acumuladas da mortalidade proporcional, até o
2 - calculate the power of discrimination, as measured by Mahalanobis 10 generalized quadratic distance $\left(D^{2}\right)$, of the accumulated percentages of deaths up to the upper limit of each age group, according to the model employed by Swaroop and Uemura ${ }^{13}$;

3 - discover the behavior, for each period, of the distribution of the countries classified in the way proposed by Swaroop and Uemura ${ }^{13}$;

4 - examine, in view of the results obtained, the convenience of modifying the definitions, both of the Proportional Mortality Ratio as also of the classifications based on its value.

\section{Formation of the Groups}

For the formation of the groups to be compared by the use of the calculation of the linear discriminating function, it was preferable to use a more objetive criterion than that used by Swaroop and Uemura ${ }^{13}$, who classified countries as "developed" and "underdeveloped" by what they knew of them a priori. Recourse was had to a health level indicator which, in terms of the variable which it represents, permitted the ordering of the countries studied, and which, for its calculation, involved proportional mortality values by age-groups; the indicator in question is that of Guedes ${ }^{7}$ (GI) (1972).

In order to determine the size of the groups to be compared, the criterion proposed by Kelley ${ }^{9}$ (1939) for the selection of groups for analysis, by means of items in educational tests, was adopted; according to that author the greatest discrimination between groups is attained when each of them, at both extremes of the ordering of the overall result of the test, includes $27 \%$ of the total number of observations. In the present case this percentage corresponds, by approximation to the whole number, to 9 countries.

Thus the group of countries designated "less developed" includes those which, according to the ranking of GI, occupy positions 1 to 9 , while those considered "more developed" occupy positions 26 to 34 .

The composition of the groups varied, from period to period, by function of the differences in evolution, in terms of GI, shown by the countries concerned.

The groups of countries which were compared in each period are presented in Table 1 , which also shows the years to which the data relate.

Another study, beyond that related to the 34 countries focussed on in the four periods and inclu. ding 66 countries, was carried out for 1980 . On the basis of the above-mentioned criterion, in this case, each group included 18 countries. 


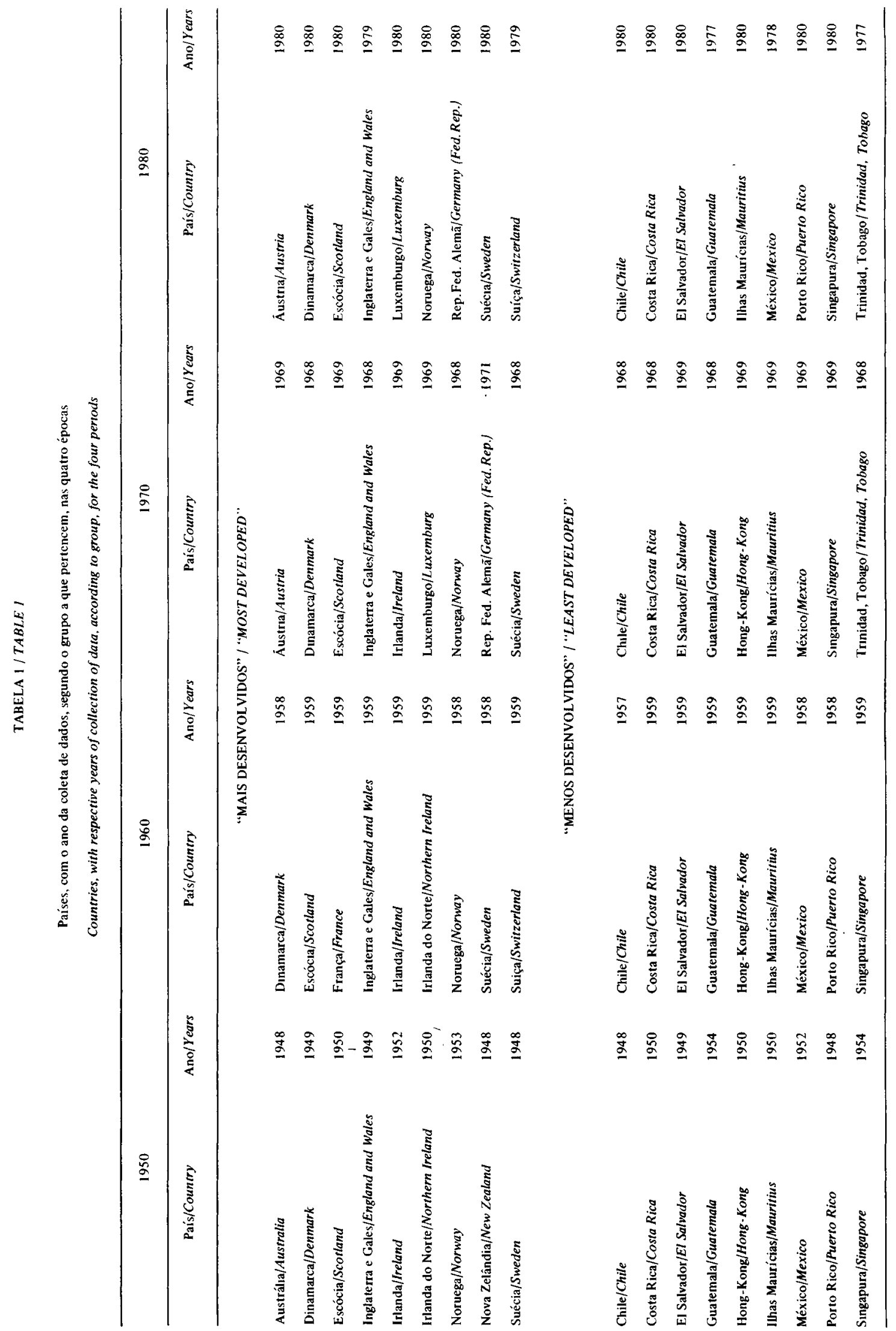


PAIVA, E.R. de et al. Razão de mortalidade proporcional de Swaroop e Uemura. Necessidade de revisão periódica de sua definição. Rev. Saúde públ., S.Paulo, 21 : 90-107, 1987.

limite superior de cada grupo etário, foi medido pelo valor da distância quadrática generalizada $\left(D^{2}\right)$ de Mahalanobis ${ }^{10}$.

Designando os grupos por A e B, temos:

$$
\mathrm{D}^{2}=\frac{\left(\overline{\mathrm{Z}}_{\mathrm{A}}-\overline{\mathrm{Z}}_{\mathrm{B}}\right)^{2}}{\begin{array}{c}
\text { variância estimada de } \mathrm{Z} \\
\text { dentro de grupos }
\end{array}}
$$

sendo $\mathrm{Z}$ uma função discriminante linear que, no caso de uma só variável, assume a forma: $Z=b X$. Para o cálculo dessa função foi seguido o modelo apresentado por Goulden ${ }^{6}$ (1951).

\section{Métodos não paramétricos de análise}

Tendo em conta a natureza dos dados a serem analisados, nas etapas seguintes do trabalho, envolvendo comparaçס̄es de distribuições em amostras não independentes, tornou-se evidente a impossibilidade de, mesmo que se recorresse a transformações das variáveis, aceitar que suas distribuiçōes satisfizessem os requisitos exigidos para o emprego de métodos paramétricos.

Foram, então, utilizados os seguintes métodos:

a) teste de Friedman (apud Holander e Wolfe ${ }^{8}$, 1973), para comparação de distribuiçōes não independentes;

b) comparaçð̃es múltiplas baseadas nas somas de postos do teste de Friedman (apud Holander e Wolfe $\left.{ }^{8}, 1973\right)$, realizadas quando o valor da estatística calculada alcançava o nível de signifi. cância.

Adaptação do método dos três grupos, de Bartlett, para estimar equaçōes de regressão em duas variáveis sujeitas a erro (apud Sokal e Rohlf ${ }^{12}, 1969$ ).

Tendo em conta que as duas variáveis envolvidas nas equações de regressão que pretendíamos estimar eram expressas, uma em percentagens e a outra em diferenças de percentagens, a utilização das médias dos dois grupos que ocupam posições ex tremas poderia suscitar questðes de ordem teórica. Além disso, a ocorrência freqüente de valores largamente discrepantes dos demais, afetando substancialmente o valor da média, constituia indicação ponderável para substituição dessa estatística pela mediana. Essa foi a única modificação introduzida, por nós, no método de Bartlett, para adaptá-lo à natureza dos dados utilizados. Cabe salientar, ainda, que não foram realizados testes de significância referen. tes às equaçōes estimadas, limitando-se a utilizá-las para o cálculo de diferenças entre valores observados e os estimados, a partir delas.

\section{Statistical Methods}

\section{Linear discriminant function}

The discriminatory power between the groups provided by the differences between the accumula. ted percentages of the proportional mortality, up to the upper limit of each age group, was measured by the value of Mahalanobis's 10 generalized quadratic distance $\left(D^{2}\right)$.

Designating the groups as $\mathrm{A}$ and $\mathrm{B}$, we get:

$$
\mathrm{D}^{2}=\frac{\left(\overline{\mathrm{Z}}_{\mathrm{A}}-\overline{\mathrm{Z}}_{\mathrm{B}}\right)^{2}}{\begin{array}{c}
\text { estimated variance of } \mathrm{Z} \\
\text { within the groups }
\end{array}}
$$

where $\mathrm{Z}$ is a linear discriminant function which, in the case of a single variable, assumes the form: $\mathbf{Z}=\mathrm{bX}$. For the calculations of this function the model presented by Goulden ${ }^{6}$ (1951) was followd.

\section{Non-parametric methods of analysis}

Bearing in mind the nature of the data to be analysed in the further stages of the study, involving comparisons of distribution in non-independent samples, the impossibility of accepting that its distributions should satisfy the requirements de. manded for the use of parametric methods, even if recourse were had to transformation of the variables, became evident.

The following methods were, therefore, used:

a) Friedman's test (in Holander and Wolfe ${ }^{8}, 1973$ ), for the comparison of non-independent distributions;

b) multiple comparisons based on the sum of the test ranks of Friedman (in Holander and Wolfe ${ }^{8}$, 1973), effected when the statistical value calculated reached the level of significance.

Adaptation of Bartlett's method for three groups for the estimation of equations of regression with two variables subject to error (in Sokal and Rohlf ${ }^{12}$, 1969)

In view of the fact that the two variables involved in the equations of regression which it was the intention to estimate were expressed, one as a percentage and the other in differences between percentages, the use of the averages of the two groups which occupy extreme positions could raise doubts of a theoretical nature. Beyond this, the frequent occurrence of values differing greatly from others, substantially affecting the value of the average, constituted a weighty reason for the replacement of this statistic by the average. This was the only modification introduced by the authors into Bartlett's method to adapt it to the nature of the data used. 
PAIVA, E.R. de et al. Swaroop and Uemura's proportional mortality ratio. The need petiodic revision of the definition. Rev. Saúde públ., S.Paulo, 21 : 90-107, 1987.

\section{Nivel de rejeiçẫo da hipótese de nulidade}

Concluiu-se pela rejeição da hipótese de nulidade, em testes de significância, quando a probabilidade de ocorrência casual do valor da estatística calculada era igual a ou menor do que 0,05 . Neste caso os valores foram assinalados com um asterisco; dois asteríscos indicam $P \leqslant 0,01$.

\section{RESULTADOS}

A observação dos valores da RMP para cada um dos países, nas quatro épocas, apresentadas na $\mathrm{Ta}$ bela 2, assegura a validade da hipótese I; de fato, apenas em um caso, o da Guatemala, de 1950 a 1960, ocorreu decréscimo do valor da RMP.
It should be, further, emphasized that it was not intended to carry out tests of significance with regard to the equations estimated, their use being limited to the calculation of differences between values observed and those estimated on the basis of them.

\section{Level of rejection of the nullity hypothesis}

The rejection of the hypothesis of nullity was decided on in tests of significance when the probability of the casual occurrence of the value of the statistic calculated was equal to, or less than, 0.05 . In this case the values were marked with an asterisk.

TABELA $2 / T A B L E 2$

Valores da Razão de Mortalidade Proporcional (50 anos ou mais) segundo países, em cada época Values of the Proportional Mortality Ratio (50 years or over), according to country, for each period

\begin{tabular}{|c|c|c|c|c|}
\hline \multirow{2}{*}{ Países/Countries } & \multicolumn{4}{|c|}{ Épocas/Periods } \\
\hline & 1950 & 1960 & 1970 & 1980 \\
\hline Austrália/Australia & 78,8 & 81,3 & 83,2 & 86,4 \\
\hline Ãustria/Austria & 74,9 & 84,6 & 88,6 & 90,8 \\
\hline Barbados/Barbados & 48,0 & 55,9 & 77,4 & 84,1 \\
\hline Canadá/Canada & 70,5 & 76,3 & 81,3 & 84,7 \\
\hline Chile/Chile & 31,2 & 38,3 & 48,8 & 68,6 \\
\hline Costa Rica/Costa Rica & 28,3 & 33,7 & 41,0 & 61,3 \\
\hline Dinamarca/Denmark & 79,1 & 86,6 & 88,6 & 91,6 \\
\hline El Salvador/El Salvador & 21,5 & 23,9 & 31,7 & 33,2 \\
\hline Escócia/Scotland & 80,8 & 86,4 & 88,8 & 91,9 \\
\hline Estados Unidos/United States & 74,3 & 79,8 & 82,8 & 85,9 \\
\hline Finlândia/Finland & 66,0 & 79,8 & 85,4 & 89,4 \\
\hline França/France & 78,1 & 86,0 & 87,6 & 89,4 \\
\hline Guatemala/Guatemala & 21,4 & 21,0 & 23,0 & 23,8 \\
\hline Hong-Kong/Hong-Kong & 17,9 & 37,0 & 69,7 & 81,4 \\
\hline Hungria/Hungary & 58,3 & 80,6 & 85,3 & 88,0 \\
\hline Ilhas Maurícias/Mauritius & 32,8 & 43,5 & 45,7 & 66,2 \\
\hline Inglaterra e Gales/England and Wales & 83,1 & 88,9 & 90,4 & 93,0 \\
\hline Irlanda/Ireland & 79,5 & 85,5 & 88,8 & 89,4 \\
\hline Irlanda do Norte/Northern Ireland & 79,5 & 85,5 & 86,8 & 89,3 \\
\hline Islândia/Iceland & 74,3 & 77,8 & 83,9 & 87,5 \\
\hline Itália/Italy & 66,0 & 77,7 & 84,6 & 90,0 \\
\hline Japāo/Japan & 44,4 & 70,2 & 79,9 & 86,4 \\
\hline Luxemburgo/Luxemburg & 78,4 & 84,1 & 88,4 & 90,4 \\
\hline México/Mexico & 27,1 & 29,0 & 33,5 & 43,6 \\
\hline Noruega/Norway & 83,6 & 86,5 & 89,6 & 92,8 \\
\hline Nova Zelândia/New Zeland & 79,5 & 80,9 & 83,9 & 86,5 \\
\hline Porto Rico/Puerto Rico & 30,0 & 50,4 & 71,9 & 77,4 \\
\hline Portugal/Portugal & 52,3 & 61,5 & 76,3 & 84,2 \\
\hline Rep.Fed. Alemã/Germany (Fed.Rep.) & 73,5 & 84,1 & 88,6 & 90,9 \\
\hline Suécia/Sweden & 82,7 & 88,7 & 90,7 & 93,2 \\
\hline Suiça/Switzerland & 76,8 & 85,3 & 87,8 & 90,7 \\
\hline Singapura/Singapore & 34,5 & 46,4 & 68,3 & 78,0 \\
\hline Trinidad, Tobago/Trinidad, Tobago & 43,9 & 52,7 & 64,1 & 72,2 \\
\hline Yugoslávia/Yugoslavia & 49,9 & 58,4 & 72,7 & 79,9 \\
\hline
\end{tabular}


PAIVA, E.R. de et al. Razâo de mortalidade proporcional de Swaroop e Uemura. Necessidade de revisão periódica de sua definiçãa. Rev. Saúde públ., S. Paulo, 21 : 90-107, 1987.

Tendo em conta a hipótese II, foi realizado, seguindo o modelo adotado por Swaroop e Uemura ${ }^{13}$, o cálculo dos valores da distância quadrática generalizada de Mahalanobis ${ }^{10}, D^{2}$, para cada percentagem de óbitos acumulados até limites crescentes de idade, confrontando os grupos de paises "mais" e "menos desenvolvidos", em cada uma das quatro épocas estudadas.

Os resultados obtidos são apresentados na Tabela 3 , cuja inspeção permite a comprovação da validade da hipótese II. De fato, o valor máximo encontrado para $\mathrm{D}^{2}$ não correspondeu, em qualquer das épocas, à percentagem acumulada de óbitos com menos de 50 anos, apontada por Swaroop e Uemura ${ }^{13}$. A classe de idades para a qual foi encontrado o maior valor de $D^{2}$ não foi a mesma nas quatro épocas, incluindo óbitos com menos de 60 anos em 1950, com menos de 70 em 1960 e com menos de 75 em 1970 e 1980.

A Tabela 3 permite, ainda, verificar-se que o poder de discriminação apresentou, via de regra, decréscimos progressivos, de década para década. Comprova-se, assim, que, como se presumia, reduziu-se progressivamente, ao longo dos $\mathbf{3 0}$ anos decorridos, a diferença entre grupos de países "mais" e "menos desenvolvidos".

Como resultante dos acréscimos da RMP, apresentados na Tabela 2, configurou-se uma situação que a Tabela 4 expressa com clareza. A distribuição dos países pelas classes definidas por Swaroop e Uemura ${ }^{13}$ modifica-se, acentuada e progressivamente, com concentração cada vez maior, à medida que as décadas se sucedem, na classe $75 \%$ ou mais. Essa situação ñ̃o sofre modificação apreciável, mesmo quando foram acrescentados, para 1980, mais 32 países. Esses resultados convalidam a hipótese III.

Alcançados esses resultados, tornou-se necessário, tendo em vista a hipótese IV, encontrar uma variável capaz de medir os deslocamentos da mortalidade para subgrupos com idades crescentes, dentro do grupo 50 anos ou mais.

Para maior simplicidade, fica, a partir deste ponto, designada a Razão de Mortalidade Proporcional por $R$; então $R_{j}$ significará essa razão quando a percentagem acumulada de óbitos é calculada a partir de $\mathbf{j}$ anos de idade. $\boldsymbol{R}_{\mathbf{j}}$ e $\boldsymbol{R}_{\mathbf{j}}$ corresponderão, respectivamente, às razões nos anos final $e$ inicial de um período.

A diferença $\underset{F}{\mathbf{R}_{j}}$ - $\underset{\mathbf{I}}{\mathbf{R}}$, ou seja, a variação dessa RMP, do início para o fim de um período, traduzirá deslocamento de óbitos; quando positiva, o deslocamento terá ocorrido da faixa de idades menores do que $\mathbf{j}$ para a de idades iguais a ou maiores do que $\mathbf{j}$; quando negativa, o que ocorreu em cerca de $1 \%$ dos

\section{RESULTS}

The observation of the PMR values for each of the countries, in the four periods, presented in Table 2, demonstrates the validity of hypothesis I; as a matter of fact only in one instance, that of Guatemala in 1950 and 1960 was there a reduction in the value for the PMR.

The calculation of Mahalanobis's generalised quadratic distance $\left(D^{2}\right)$ was carried out, with a view to testing hypothesis II, according to the model adopted by Swaroop and Uemura, for each percentage of accumulated deaths up to increasing age limits, contrasting the groups of countries "more" and "less" developed, for each of the four periods studied.

The results obtained are presented in Table 3 , a reading of which shows the validity of hypothesis II. As a matter of fact the highest value found for $\mathrm{D}^{2}$ did not correspond, for any of the periods, to the accumulated percentage of deaths at below fifty years of age indicated by Swaroop and Uemura. The grouping of ages for which the highest value of $D^{2}$ was found was not the same in the four periods, including deaths below 60 years of age in 1950, with less than 70 in 1970 and with less than 75 in 1970 and 1980.

Table 3 allows, further, verification of the fact that the power of discrimination showed, as a general rule, progressive decreases, from decade to decade. Thus was verified the supposition that the difference between the groups of countries "more" and "less" developed was progressively reduced over the period of 30 years.

As a result of the growth of the PMR, as shown in Table 2, the situation which Table 4 expresses with clarity appeared. The distribution of countries according to the classes defined by Swaroop and Uemura $^{13}$ has changed clearly and progressively, with an increasingly higher concentration, with each passing decade, in the class of $75 \%$ and above. This position suffered no appreciable modification even when a further 32 countries were added, for 1980 . These results corroborate hypothesis III.

Once these results had been achieved it became necessary, with the hypothesis IV, in mind, to find a variable capable of measuring the displacements of mortality to subgroups of increasing age, within the group of 50 or more years of age.

For the sake of greater simplicity, from this point on, the Proportional Mortality Ratio will be designated by $R$. Thus $R_{j}$ will signify this rate when the accumulated percentage of deaths is calculated from $j$ years of age. $\mathbb{R}_{j}$ e $\mathbb{R}_{\mathbf{j}}$ will correspond, respectively, to the rates in the final and initial years of a period. 
PAIVA, E.R. de et al. Swaroop and Uemura's proportional mortality ratio. The need periodic revision of the definition. Rev. Saúde públ., S.Paulo, $21: 90-107,1987$.

\section{TABELA 3 / TABLE 3}

Valores de $\mathrm{D}^{2}$, em cada época, segundo a idade limite para acumulação da percentagem de óbitos Values of $D^{2}$ for each period, according to the limiting age for the accumulation of percentages of deaths

\begin{tabular}{|c|c|c|c|c|c|}
\hline \multirow{2}{*}{$\begin{array}{l}\text { Idade Limite } \\
\text { Limiting age }\end{array}$} & \multicolumn{5}{|c|}{$\mathrm{D}^{2}$} \\
\hline & 1950 & 1960 & & 1970 & 1980 \\
\hline$<1$ & 84,9 & 37,1 & & 8,5 & 5,0 \\
\hline$<5$ & 97,1 & 34,5 & & 7,4 & 3,0 \\
\hline$<10$ & 84,1 & 47,7 & & 7,1 & 2,9 \\
\hline$<15$ & 83,0 & 31,4 & & 7,2 & 3,1 \\
\hline$<20$ & 87,6 & 31,3 & & 7,6 & 3,4 \\
\hline$<25$ & 96,6 & 31,5 & & 7,9 & 3,8 \\
\hline$<30$ & 101,4 & 31,7 & & 8,1 & 4,1 \\
\hline$<35$ & 110,4 & 33,6 & & 8,5 & 4,4 \\
\hline$<40$ & 116,2 & 36,8 & - & 9,1 & 4,6 \\
\hline$<45$ & 130,5 & 41,6 & & 10,3 & 4,6 \\
\hline$<50$ & 131,6 & 50,1 & & 12,2 & 5,6 \\
\hline$<55$ & 183,8 & 60,4 & & 16,1 & 6,6 \\
\hline$<60$ & 197,6 & 70,6 & & 23,2 & 8,1 \\
\hline$<65$ & 166,7 & 73,6 & & 32,1 & 10,7 \\
\hline$<70$ & 112,6 & 77,5 & & 42,8 & 13,9 \\
\hline$<75$ & 68,3 & 67,7 & & 43,8 & 14,9 \\
\hline$<80$ & 28,4 & 36,4 & & 34,1 & 11,9 \\
\hline$<85$ & 9,3 & 12,3 & & 17,2 & 5,3 \\
\hline $\begin{array}{l}\text { le postos } \\
\text { ranks }\end{array}$ & 68 & 55 & & 39 & 18 \\
\hline
\end{tabular}

Teste de Friedman/Friedman's test

$$
\begin{aligned}
& X^{2} \text { calculado/ } X^{2} \text { calculated }=46,47 * \\
& X^{2} \text { crítico/critical value for } X^{2}=X^{2}(3 \mathrm{GL} ; 0,05)=7,82 \\
& X^{2} \text { crítico/critical value for } X^{2}=X^{2}(3 \mathrm{GL} ; 0,01)=16,27
\end{aligned}
$$

Comparaçðes múltiplas/Multiple comparisons

Diferença entre soma de postos/Difference between the sum of the ranks

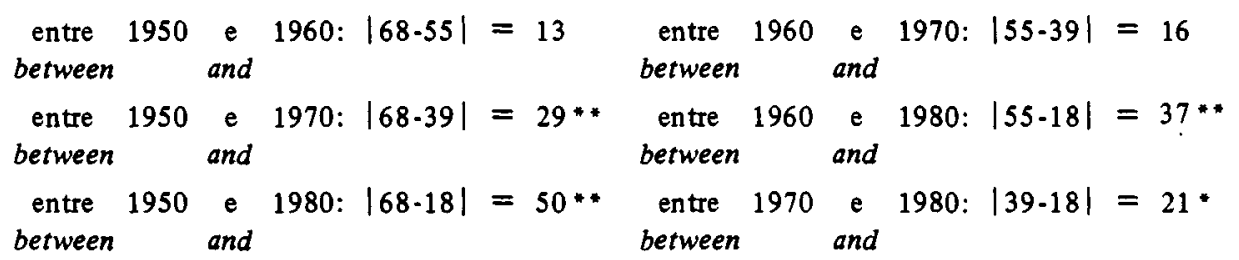

Taxa de erro experimental/ Rate of experimental error

$$
\begin{aligned}
& \alpha=0,01 \\
& \alpha=0,05 \\
& \alpha=0,10
\end{aligned}
$$

Diferença mínima significante/ Significant minimum difference 
PAIVA, E.R. de et al. Razão de mortalidade proporcional de Swaroop e Uemura. Necessidade de revisão periódica de sua definição. Rev. Saúde públ., S.Paulo, $21: 90-107,1987$.

\section{TABELA $4 / T A B L E 4$}

Países estudados, segundo classes propostas por Swaroop e Uemura, em cada época Countries studied, according to the classes proposed by Swaroop and Uemura, for each period

\begin{tabular}{|c|c|c|c|c|c|c|c|c|c|c|}
\hline \multirow{3}{*}{$\begin{array}{c}\text { Classes/Classes } \\
\text { (RMP: } 50 \text { anos ou mais/ } \\
\text { (PMR: } 50 \text { years or above }\end{array}$} & \multicolumn{10}{|c|}{ Epocas/Periods } \\
\hline & \multicolumn{2}{|c|}{1950} & \multicolumn{2}{|c|}{1960} & \multicolumn{2}{|c|}{1970} & \multicolumn{2}{|c|}{1980} & \multicolumn{2}{|c|}{$1980^{*}$} \\
\hline & Nọ & $\%$ & No & $\%$ & No & $\%$ & N? & $\%$ & No & $\%$ \\
\hline $\begin{array}{l}\text { até } 24 \\
\text { up to } 24\end{array}$ & 3 & 8,8 & 2 & 5,9 & 1 & 2,9 & 1 & 2,9 & 1 & 1,5 \\
\hline $\begin{array}{l}25 \text { até } 49 \\
25 \text { to } 49\end{array}$ & 10 & 29,4 & 6 & 17,6 & 5 & 14,7 & 2 & 5,9 & 9 & 13,6 \\
\hline $\begin{array}{l}50 \text { até } 74 \\
50 \text { to } 74\end{array}$ & 9 & 26,5 & 6 & 17,6 & 5 & 14,7 & 4 & 11,8 & 14 & 21,2 \\
\hline $\begin{array}{c}75 \text { ou }+ \\
75 \text { and above }\end{array}$ & 12 & 35,3 & 20 & 58,8 & $\begin{array}{c}23 \\
-\end{array}$ & 67,6 & 27 & 79,4 & 42 & 63,6 \\
\hline Total & 34 & 100,0 & 34 & 100,0 & 34 & 100,0 & 34 & 100,0 & 66 & 100,0 \\
\hline
\end{tabular}

* Distribuição, pelas classes, dos 66 países para os quais se dispôs de dados em 1980

* Distribution, in accordance with the classes, of the 66 countries for with data were available in 1980.

casos, o sentido do deslocamento será o inverso. Ainda para maior simplicidade, faremos

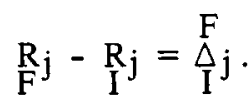

A percentagem de óbitos, no ano I, com menos de $\mathbf{j}$ anos de idade, é dada, evidentemente, por $100-\mathrm{R}_{\mathrm{j}}$, podendo sofrer decréscimo ou acréscimo até o ano $F$, conforme $\triangle_{I} j$ seja positivo ou negativo, respectivamente.

Se designarmos por $\underset{I}{p_{j}}$, o decréscimo ou acrésci. mo relativo dessas percentagens de óbitos com menos de $\mathrm{j}$ anos de idade, durante o período de $\mathbf{I}$ a $\mathrm{F}$, em termos de percentagem do valor no ano $I$, tem-se

$$
\underset{\text { I }}{F}=\frac{\stackrel{F}{\Delta}_{j}}{100-\underbrace{R}_{\text {I }}} \times 100
$$

Assim definida a medida dos deslocamentos relativos para idades iguais a ou maiores do que $j$, tornou-se possível o estudo da validade da hipótese IV, mediante o cálculo de equaçōes de regressão entre $\stackrel{\mathrm{I}}{\triangle}_{\mathrm{j}}$ e ${\underset{\mathrm{I}}{\mathrm{P}} \mathrm{j}}_{\mathrm{j}}^{\mathrm{F}}$, permitindo a definição de uma nova variável representada pelo módulo da diferença entre os valores observados de $\mathrm{F}$ e os estimados segundo $\mathrm{p}_{\mathrm{j}}$
The difference $\mathrm{R}_{\mathbf{F}} \mathbf{j}-\mathrm{R}_{\mathbf{I}}$, that is, the variation of the PMR, as between the beginning and end of a period, will represent the displacement of deaths; when positive, the displacement will have occurred from the group of ages below $j$ to that of ages equal to or greater than $j$; when negative, as happened in some $1 \%$ of cases, the direction of the displacement will be the opposite. For even greater simplicity, we will make

$$
\underset{F}{R} \mathbf{j}-\underset{I}{R_{j}}=\stackrel{F}{\Delta} \mathbf{j}
$$

The percentage of deaths, in year $I$, at less than $j$ years of age, is given, evidently, by $100-\mathrm{R}_{\mathrm{I}}$, and may decrease or increase up to year $F$, according

as $\underset{\mathrm{I}}{\Delta} \mathrm{j}$ be, respectively, positive or negative.
If, by $\underset{\mathrm{I}}{\mathrm{F}} \mathrm{j}$, is designated the relative decrease or increase of these percentages of deaths with less than $j$ years of age, during the period from $I$ to $F$, the result, in terms of percentages for the value of the year $I$; is:

$$
\underset{\mathrm{I}}{\mathrm{F}} \mathrm{j}=\frac{\stackrel{F}{\triangle} \mathrm{j}}{100-\underset{\mathrm{I}}{\mathrm{R}_{j}}} \times 100
$$

With the measure of the relative displacements for ages equal to or greater than $\mathrm{j}$ thus defined, the study of hypothesis IV became possible, by means of the calculation of the equations of regression 
PAIVA, E.R. de et al. Swaroop and Uemura's proportional mortality ratio. The need periodic revision of the definition.Rev.Saúde públ, S. Paulo, 21 : 90-107, 1987.

a equação; em cada período considerado, e para cada $\Delta_{\mathfrak{j}}$, essa diferença pode ser expressa, simplificadamente, por $\left|p_{j}-\hat{p}_{j}\right|$.

Assim, em um dado período, para cada valor de $\mathrm{j}$, em $p_{j}$, correspondem tantas equaçбes de regressão quantos forem os valores atribuídos a $\mathrm{j}$ em $\Delta_{j}$. Cada uma dessas equaçōes proporciona uma distribuição de valores da variável acima definida.

A comparação dessas distribuições permite, então, que se verifique, para o periodo em causa, qual dos $\Delta_{j}$ propicia melhor predição dos valores de $p_{j}$, ou seja, dos deslocamentos relativos de óbitos de idades menores do que $\mathrm{j}$ para iguais ou maiores.

As idades selecionadas, para cálculo dos $\underset{\mathrm{I}}{\mathrm{F}} \mathrm{j}$, foram: 50,65 e 75 anos; a primeira por ser a definida por Swaroop e Uemura, e as demais, terminadas em 5 , não só porque se ajustam à distribuição etária que figura no "World Health Statistics Annual" da Organização Mundial da Saúde, como também porque com elas é reduzida a causa de erro representada pelos arredondamentos da idade para o final zero. Também porque, como se vê na Tabela 3 , o valor máximo de $D^{2}$ corresponde ou a uma delas, ou a outra idade de que uma se aproxima.

No caso de $\underset{\mathrm{I}}{\mathrm{F}} \mathrm{j}$ foram utilizadas, a partir de 50 anos, as idades terminadas em 0 ou 5 , até 80 . Foram estudados os períodos anteriormente considerados, ou seja: 1970.1980, 1960.1980, 1950-1980, 1960-1970, 1950-1970 e 1950-1960.

Os valores de $\underset{\mathbf{I}}{\stackrel{F}{\Delta}} \mathbf{j}$, de $100 \cdot R_{j}$ e de $\underset{\mathrm{I}}{\mathrm{p}}$, calculados para cada país, constituem os elementos básicos para os estudos a serem a seguir desenvolvidos. Houve impossibilidade de apresentação, pela limitação de espaço, das tabelas em que figuram esses valores, para cada uma das épocas estudadas *

Recorrendo à adaptação do método dos três grupos, de Bartlett (apud Sokal e Rholf12), foram calculadas as equações de regressão de $\underset{\text { I }}{\mathbf{F}} \underset{j}{\text { em }} \underset{\mathbf{I}}{\stackrel{F}{\Delta}} \mathbf{j}$.

Foram então calculados, para cada período, os valores de $\left|\mathrm{p}_{j}-\hat{\mathrm{p}}_{\mathrm{j}}\right|$; que, ainda, pela limitação de espaço, deixaram de ser apresentados*. Em cada período, para um mesmo valor de $\mathrm{j}$, em $\mathrm{p}_{\mathfrak{j}}$, tem-se três distribuições de valores de $\left|\mathbf{p}_{\mathbf{j}}-\hat{p}_{\mathbf{j}}\right|$, correspondentes às equaçōes que incluem $\Delta_{75}, \Delta_{65}$ e $\Delta_{50}$. Para comparação dessas distribuiçōes foi utilizado o teste de Friedman (apud Hollander e Wolfer ${ }^{8}$ ).

Na Tabela 5 são apresentados os valores da esta. tística $\mathrm{S}$ calculados para cada um dos testes de between $\underset{I}{\stackrel{F}{\Delta}} j$ and $\underset{I}{P} j$, allowing the definition of a new variable represented by the module of the difference between the observed values of

between the observed values of $\underset{\mathrm{I}}{\mathrm{P}} \mathrm{j}$ and the estimates made on the besis of the equation. In each period considered, and for each $\Delta_{j}$, this difference can be expressed, in a simplified form, by $\left|p_{j}-\hat{p}_{j}\right|$.

Thus, in each period, for each value of $j$, in $p_{j}$, there will be as many equations of regression as there are values attributed to $j$ in $\Delta_{j}$. Each of these equations will give a distribution of values for the above-defined variable.

The comparison of these distributions will then permit the verification as to which of the $\Delta_{j}$, for the period in question, will provide the best forecast of the values of $\mathrm{p}_{j}$, that is to say, of the relative displacement of deaths for ages less than $j$ towards ages equal to or greater than $j$.

The ages selected for the calculation of the ${ }_{\mathrm{I}} \triangle_{j}$ were 50,65 and 75 years - the first because it was that defined by Swaroop and Uemura, and the others, finishing in 5, not only because they correspond to the age distribution which appears in the World Health Statistics Annual edited by World Health Organization, but also because, by their use, the source of error represented by the rounding off of the age to the final 0 is reduced. Further because, as can be seen from Table 3, the greatest value for $\mathrm{D}^{2}$ corresponds to one of them or to another age to which it approximates.

In the case of $\underset{\mathrm{I}}{\mathrm{F}} \mathrm{j}$, ages ending in 0 or 5 , from 50 up to 80 inclusive, were used. They were studied for the periods previously considered, namely: 1970 - 1980, 1960 - 1980, 1950 - 1980, 1960 $-1970,1950-1970$ and $1950-1960$.

The values of $\underset{I}{\triangle} \triangle_{j}$, of $100-R_{j}$ and of $\underset{1}{F}$, calculated for each country, constituted the basic elements for the studies to be elaborated from this point on. Because of limitations of space it is impossible to present the tables of these values.

The equations of regression from $\underset{I}{p_{j}}$ to $\underset{\Delta_{j}}{F}$ were calculated by means of the adaptation of Bartlett's (in Sokal and Rholfi2) three-group method.

Then were calculated, for each period, the values of $\left|p_{j}-\hat{p}_{j}\right|$, which, again for reasons of space, are not presented *. As can be seen, in each period, for one and the same value of $j$, in $p_{j}$ there are three

- Os leitores interessados poderão solicitar as tabelas aos autores, no endereço constante da primeira página deste artigo. The tables will be supplied on request by the authors. 
PAIVA, E.R. de et al. Swaroop and Uemura's proportional mortality ratio. The need periodic revision of the definition. Rev. Saúde públ., S.Paulo, 21 : 90-107, 1987.

Friedman, bem como as diferenças obtidas nas comparações múltiplas. Deve-se lembrar que, quando a estatística $S$ não alcançou o nível crítico, os valores dessas diferenças foram apresentados apenas como ponto de referência, sem se pretender referílos ao valor crítico da diferença mínima significante.

\section{O exame da Tabela 5 permite verificar que:}

a) nos casos das distribuições referentes a $p_{70}, p_{75}$ e $\mathrm{p}_{80}$, traduzindo deslocamentos de óbitos de idades menores para iguais ou maiores do que as indicadas, a estatística $S$ ultrapassou, nos 18 testes, o valor crítico, mesmo para o nivel de significância dado por $\alpha=0,01$; nas comparações múltiplas, as somas de postos referentes às equações que envolvem $\Delta_{\text {so }}$ foram, também sem exceção, significantemente maiores do que as proporcionadas pelas equações de que participa $\Delta_{75}$, ou seja, os desvios, naquelas, foram maiores do que nestas; as somas de postos, referentes a $\Delta_{50}$, foram também sempre maiores do que as fornecidas por $\Delta_{65}$, com significância da diferença, à taxa de erro experimental igual a 0,05 , em três casos; em outros três, a significância foi alcançada $\operatorname{com} \alpha=0,10$; a soma de postos, referente a $\Delta_{65}$ foi sempre, com exceção de um único caso, maior do que a obtida com $\Delta_{75}$, sendo alcançado o nível de significância por 12 vezes à taxa de erro experimental igual a 0,05 , e em outras duas à taxa de 0,10 ;

b) de $p_{50}$ até $p_{65}$, a estatística $S$ alcançou o nível de significância em 10 das 24 comparações; em cinco delas correspondendo a menor soma de postos às equações com $\Delta_{65} \mathrm{e}$, nas cinco outras, às equa. ções com $\Delta_{75}$. Nas 14 comparações em que $S$ mostrou valor menor do que o crítico, em seis a menor soma correspondeu a $\Delta_{75}$, em oito a $\Delta_{65}$. Nas comparações múltiplas com taxa de erro experimental igual a 0,05 a soma de postos referente a $\Delta_{75}$ foi, por três vezes, significantemente menor do que a referente a $\Delta_{65}$, e por seis vezes, menor do que a correspondente a $\Delta_{50}$, sendo que, por cinco vezes, a com $\Delta_{65}$ foi menor do que a com $\Delta_{50}$. Com taxa de erro experimental igual a 0,10 , a soma de postos com $\Delta_{65}$ foi por duas vezes significantemente menor do que a obtida com $\Delta_{75}$ e, uma vez, do que a referente a $\Delta_{50}$; uma vez a soma de postos com $\Delta_{75}$ foi menor do que a com $\Delta_{65}$ e outra vez, menor do que a referente a $\Delta_{50}$.

Esse conjunto de resultados evidencia que os deslocamentos relativos de óbitos, de idades menores para iguais a ou maiores do que 70,75 e 80 anos, foram melhor traduzidos pelas variações, durante um dado período, da razão de mortalidade proporcional que representa a percentagem de óbitos com 75 ou mais anos de idade. Quando os deslocamentos distributions of the values of $\left|p_{j}-\hat{p}_{j}\right|$, correspon. ding to the equations which include $\Delta_{75}, \Delta_{65}$ and $\Delta_{50}$. Friedman's test was used for the comparison of these distributions, and the values for the sums of the positions $\left(\Sigma_{\Delta \mathbf{j}}\right)$ related to each distribution, appear in the same table.

Values for the statistic $S$ are presented in Table 5. They have been calculated for each of Friedman's tests (Hollander and Wolfer ${ }^{8}$ ), as also were the differences obtained in the multiple comparisons. It should be remembered that, when the statistic $S$ did not reach the critical level, the values of the differences were presented only as points of reference, without there being any pretension to relate them to the critical value of the significant minimum difference.

An examination of Table 5 allows the verification that:

a) in the cases of the distributions related to $p_{70}$, $\mathrm{p}_{75}$ and $\mathrm{p}_{80}$, transposing displacements of deaths from lower ages to ages equal to or greater than those shown, the statistic $S$, in the 18 tests, passed the critical value, even for the level of significance given by $\alpha=0.01$; in the multiple comparisons the sums of the positions related to the equations involving $\Delta_{50}$ were, also without exception, significantly greater than those given by the equations in which $\Delta_{75}$ was involved, that is to say, the shifts in the former were greater than those in the latter; the sums of the ranks, relating to $\Delta_{50}$, were also always greater than those given by $\Delta_{65}$, with a difference of significance, for a rate of experimental error equal to 0.05 , in three cases; in another three, significance was reached when $\alpha=0.10$; the sum of the ranks related to the equations with $\Delta_{65}$ was always, with the exception of one single case, greater than that obtained with $\Delta_{75}$, and the level of significance was reached 12 times for the experimental rate of error equal to 0.05 , and in another two instances for the rate of 0.10 ;

b) from $\mathrm{p}_{50}$ up to $\mathrm{p}_{65}$ the statistic $S$ reached the level of significance in 10 of the 24 comparisons; in five of them the smallest sum of the ranks corresponded to the equations with $\Delta_{65}$ and, in the five others, to the equations with $\Delta_{75}$. In the 14 comparisons in which $\mathrm{S}$ showed a lower than critical value, in six of them the smallest sum corresponded to $\Delta_{75}$ and in eight to $\Delta_{65}$. In the multiple comparisons with a rate of experimental error equal to 0.05 the sum of the positions related to $\Delta_{75}$ was, three times, significantly less than that related to $\Delta_{65}$, and six times less than that corresponding to $\Delta_{50}$ and five times that with $\Delta_{65}$ was less than that with $\Delta_{50}$. With a rate of experimental error equal to 0.10 the sum of the ranks with $\Delta_{65}$ was twice significantly less 
PAIVA, E.R. de et al, Razão de mortalidade proporcional de Swaroop e Uemura. Necessiđade de revisão petiódica de sua definição. Rev.`zúde públ., S. Paulo, 21 : 90-107, 1987.

de óbitos se referiram a 50, 55, 60 e 65 anos, merecem ser consideradas as duas razões, incluindo óbitos com 65 ou mais ou com 75 ou mais.

Assim, os resultados obtidos com o método utilizado mostram que as variações, durante um período, da razão de mortalidade proporcional, como proposta por Swaroop e Uemura ${ }^{13}$, não permitem pre. visoes tão ajustadas quanto as proporcionadas pelas razões referentes a 65 ou a 75 anos de idade, dos deslocamentos relativos a óbitos para qualquer das classes de idades focalizadas neste estudo. Pode, então, ser admitida a validade da hipótese IV.

\section{PROPOSIÇŌES DECORRENTES DA ANÁLISE DOS RESULTADOS}

Os resultados apresentados na Tabela 3 permitiram que fossem evidenciados dois importantes pontos a serem tomados em consideração:

19) em nenhuma das épocas estudadas, o valor má. ximo de $\mathrm{D}^{2}$ foi o referente à percentagem acumulada de óbitos com menos de 50 anos de idade, o que vale dizer para a percentagem de óbitos com 50 anos ou mais;

29) o grupo etário a que correspondeu esse valor máximo variou no decorrer do período estudado.

Seguindo o critério adotado por Swaroop e Uemura ${ }^{13}$, a RMP deveria ser representada pela mortalidade com 60 anos ou mais, em 1950, com 70 anos ou mais em 1960 e com 75 anos ou mais em 1970 e 1980. É evidente, porém, que comparações ao longo do tempo somente têm sentido quando o valor da RMP se refere à mesma faixa de idades.

Coloca-se, então, o problema de escolha do novo valor para definir a RMP. Desde logo podem ser lembradas razões que desaconselham a opção pelos valores de 60 ou 70. De fato, nos grupos etários adotados pela Organização Mundial de Saúde, para as distribuições de óbitos que figuram no "World Health Statistics Annual", por ela editado, as classes têm, como limite superior, o valor médio entre as dezenas, excetuando-se, apenas, a referente aos óbitos no primeiro ano de vida. Sendo o Anuário uma das mais utilizadas fontes de dados em estatísticas vitais, as estimativas para grupos etários com limite, ou limites, terminados em zero, implicam a necessidade de interpolações, sujeitas naturalmente, a erros de maior ou menor monta. A utilização de tais limites poderia ser justificada recorrendo-se, como fonte de dados, ao Demographic Yearbook, em que a distribuição dos óbitos é apresentada segundo classes com intervalos de 5 anos; como foi apontado, essa foi a razão para recorrer a essa fonte, dada a metodologia que se pretendia adotar no trabalho. É evidente, porém, que se deixa de dispor de dados eventualmente apresentados apenas na publicação da $\mathrm{OMS}^{11}$. than that obtained with $\Delta_{75}$ and once than that related to $\Delta_{50}$; once the sum of the ranks with $\Delta_{75}$ was less than that with $\Delta_{65}$ and one other time less than that related to $\Delta_{50}$.

These results, taken together, demonstrate that the relative displacements of deaths, from lower ages to those equal to or higher than 70,75 and 80 , were better interpreted by the variations, during any given period, of the proportional mortality rate which represents the percentage of deaths at 75 years of age or above. When the displacements of deaths referred to $50,55,60$ and 65 years of age, both rates deserve to be taken into consideration, those including deaths at 65 or more and at 75 or above.

Thus the results obtained by the method used show that the variations, within any one period, of the proportional mortality ratio, as proposed by Swaroop and Uemura ${ }^{13}$, do not allow such exact forecasts as those provided by the ratios related to 65 or 75 years of age, of the relative displacements of deaths to any of the age-classifications focussed on in this study. Thus the validity of hypothesis IV, may be admitted.

\section{PROPOSITIONS ARISING FROM THE ANALYSIS OF THE RESULTS}

The results presented in Table 3 made two important points, which must be taken into consideration, evident:

1st) in none of the periods studied was the maximum value of $\mathrm{D}^{2}$ that which referred to the accumulated percentage of deaths with less than 50 years of age, wich means to say that it was always greater for the percentage of deaths at 50 or more years of age;

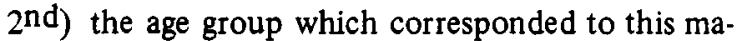
ximum value varied during the period studied.

According to the criterion adopted by Swaroop and Uemura ${ }^{13}$, the PMR should be represented by mortality at 60 years or above in 1950 , at 70 years or over in 1960 and at 75 years or over in 1970 and 1980. It is evident, however, that comparisons through time only make sense when the value of the PMR refers to the same age group.

There then arises the problem of the choice of the new value for the definition of the PMR. Immediately reasons come to mind against the choice of the values 60 and 70 . It is true that in the age groups adopted by the World Health Organization for the distribution of deaths which appears in the World Health Statistics Annual, edited by the WHO, the classifications have, as their upper limits, the mean value between the tens, with the single exception of that which refers to deaths in the first year of life. As the Yearbock is one of the most widely used sources of data on vital statistics, the estimates for 
PAIVA, E.R. de et al. Swaroop and Uemura's proportional mortality ratio. The need periodic revision of the definition. Rev.Saúde públ., S.Paulo, $21: 90-107,1987$.

Assim, restam como opçōes os valores de 65 ou 75 para a idade que figura na definição da RMP, podendo ser apontadas as seguintes vantagens ligadas à escolha da segunda:

a - Ter sido essa a faixa etária com maior poder de discriminação nas duas épocas mais recentes; em outra, 1960, esse poder ainda se mostrou bastante elevado, aproximando-se do correspondente a 65 anos ou mais.

b - A faixa 75 anos ou mais é a que permite melhor previsão, em termos de suas variações, do início para o fim de um período, da magnitude relativa dos deslocamentos de óbitos para grupos etários mais elevados, especialmente acima de 70 anns

Entretanto, tendo em vista que deslocamentos de óbitos para classes com limite inferior igual a 50 , 55,60 ou 65 anos, tiveram bom relacionamento com as variações da RMP definida por óbitos com 65 anos ou mais, por vezes melhor do que o referente a 75 anos ou mais, é aconselhável a consideração deste indicador para complementar a apreciação da evolução, durante um determinado período, do nivel de saúde de uma população.

Outro aspecto relevante a ser examinado diz respeito à comprovação, como demonstrado na apresentação dos resultados, de que a ordenação em am. plas classes, com os limites propostos por Swaroop e Uemura ${ }^{13}$, não mais permitiria descrever a posição relativa dos países, em termos de nível de saúde, quando adotada a faixa de 50 anos ou mais para de. finição da RMP.

Com a nova definição sugerida, modificar-se-ia a distribuição dos países pelas mesmas classes, como se vê na Tabela 6

Com o exame da Tabela 6 pode-se verificar, desde logo, que também em termos da nova definição da RMP, ficam evidenciados os avanços, em termos de nível de saúde, apresentados pelos países estudados. Há, entretanto, concentração na classe 2550 e ficam vazias duas classes, até 1970, e uma em 1980. Neste ano, tanto para os 34 como para os 66 países, o maior valor observado foi 55,0 , distante ainda do limite superior da classe 5075 .

Assim, além de, como foi visto, não mais resultar classificação expressiva dos países, quando definida a RMP em termos de 50 anos ou mais, as classes propostas por Swaroop e Uemura ${ }^{13}$ também não são as mais adequadas para essa classificação segundo a variável que resulta de nova definição da RMP, ou seja, percentagem de óbitos com 75 anos ou mais.

Tendo em conta as situaçōes passada e atual, bem como mantendo a possibilidade de ampliação futura, parece digna de consideração a proposição de novos age-groups with limit or limits ending in zero in. volve the need for interpolations, naturally subject to errors of greater or lesser weight. The use of such limits could be justified by reference, as a data source, to the Demographic Yearbook, in which the distribution of deaths is presented by classes with five year intervals; as has already been mentioned, this was the reason which led to the use of this source in the light of the methodology envisaged for this study. It is evident, however, that in this way data which may be presented solely in the WHO publication ${ }^{14}$ are left aside.

For these reasons, there remain as options the values of 65 and 75 for the age which may be used in the definition of the PMR, and the following advantages may be indicated with regard to the choice of the latter:

$1^{\text {st }}$. this has been the age-group with the greatest discriminatory power in the two most recent periods; in another, 1960, this power still showed itself to be quite high, approximating to that corresponding to 65 years of age and above;

$2^{\text {nd }}$ - the group 75 years or above is that which permits the best forecast, in terms of its varia. tions, from the beginning to the end of a period, of the relative magnitude of the displacements of deaths to higher age-groups, especially above 70 years of age.

However, in view of the fact that the displacement of deaths to classes with the lower limits equal to $50,55,60$ or 65 years, had a good relationship with the variations of the PMR defined for deaths at 65 years of age or above, at times better than that refering to 75 years or above, the considera. tion of this indicator as a means to complement the evaluation of the evolution of the level of health of a population, during a particular period, is advisable.

Another relevant aspect worthy of examination is related to the corroboration, as demonstrated in the appreciation of the results, that the ordering in wide classes, with the limits proposed by Swaroop and Uemura, would no longer permit the description of the countries' relative positions, in terms of health level, when the group of 50 years of age or above was adopted for the definition of the PMR.

According to the new definition suggested, the distribution of the countries into the same classes would undergo modification, as may be seen in Table 6.

An examination of Table 6 enables one to verify immediately, also in terms of the new definition of the PMR, the progress, in terms of health levels, presented by the countries studied. There is however a concentration in the classification $25 \vdash 50$ and two classifications remain empty, up to 1970 , and one in 1980. In this last year, as much for the 34 as for 
PAIVA, E.R. de et al. Razão de mortalidade proporcional de Swaroop e Uemura. Necessidade de revisão periódica de sua definição. Rev. Saúde públ., S.Paulo, 21 : 90-107, 1987.

\section{TABELA $6 / T A B L E 6$}

Países, segundo o valor da $\mathrm{RMP}_{75}$, em classes com os limites propostos por Swaroop e Uemura, nas diferentes épocas

Countries, according to the value PMR 75 , in groups with the limits proposed by Swaroop and Uemura, for the different periods

\begin{tabular}{|c|c|c|c|c|c|c|c|c|c|c|}
\hline \multirow{3}{*}{$\begin{array}{l}\mathrm{RMP}_{75} \\
\operatorname{PMR}_{75}\end{array}$} & \multicolumn{9}{|c|}{ Epocas / Periods } & \\
\hline & \multicolumn{2}{|c|}{1950} & \multicolumn{2}{|c|}{1960} & \multicolumn{2}{|c|}{1970} & \multicolumn{2}{|c|}{1980} & \multicolumn{2}{|c|}{$1980^{x}$} \\
\hline & No & $\%$ & No & $\%$ & No & $\%$ & No & $\%$ & No & $\%$ \\
\hline $0 \longmapsto 25$ & 16 & 47,1 & 11 & 32,4 & 9 & 26,5 & 4 & 11,8 & 18 & 27,3 \\
\hline $25 \longmapsto 50$ & 18 & 52,9 & 23 & 67,6 & 25 & 73,5 & 22 & 64,7 & 37 & 56,1 \\
\hline $50 \longmapsto 75$ & 0 & 0,0 & 0 & 0,0 & 0 & 0,0 & 8 & 23,5 & 11 & 16,7 \\
\hline $75 \vdash 100$ & 0 & 0,0 & 0 & 0,0 & 0 & 0,0 & 0 & 0,0 & 0 & 0,0 \\
\hline
\end{tabular}

Xistribuição, pelas classes, dos 66 países estudados apenas em 1980

Distribution, among the groups of the 66 countries studied only in 1980

limites de classe como se vê na Tabela 7 , em que são apresentadas as distribuiçōes que resultariam, nas quatro épocas, se adotadas essas novas classes.

Pode-se prever que, com a continuação dos progressos em nível de saúde, a classe $0 \vdash 20$ tende a se esvaziar, enquanto a $55 \longmapsto$, vazia até 1970 , povoar-se-á progressivamente. É mesmo possivel que venha a ser conveniente estabelecer para ela um limite superior, fazendo-a igual a $55 \longmapsto 60$, dando origem a uma nova classe de 60 -

\section{CONCLUSŐES}

Os resultados obtidos e analisados, referentes a países estudados em anos próximos de 1950, 1960, 1970 e 1980, permitem a formulação das seguintes conclusões:

1 . No confronto entre países "mais e menos desenvolvidos", envolvendo percentagens acumu- the 66 countries, the highest value observed was 55.0 , still far removed from the upper limit of the class $50 \vdash 75$.

Thus, the classification proposed by Swaroop and Uemura ${ }^{13}$, beyond not giving, as has already been seen, a meaningful differentiation of the countries when the PMR is defined in terms of 50 years of age or above, is also not the most adequate for this classification according to the variable which results from the new definition of the PMR, that is to say, the percentage of deaths at 75 or more years of age.

Bearing in mind the past and present situations, as well as with a view to the possibility of future development, the proposition of new classification limits as set out in Table 7 seems worthy of consideration. In this table are presented the distributions which would result, for the four periods, if these new classes were adopted.

TABELA $7 / T A B L E 7$

Países, segundo as classes de valores de $\mathrm{RMP}_{75}$, nas quatro épocas estudadas

Countries, according to the classification of the values of $P M R_{75}$ for the four periods studied

\begin{tabular}{|c|c|c|c|c|c|c|c|c|c|c|c|}
\hline \multirow{3}{*}{$\begin{array}{l}\mathrm{RMP}_{75} \\
\operatorname{PMR}_{75}\end{array}$} & & \multicolumn{8}{|c|}{ Epocas / Periods } & & \\
\hline & & \multicolumn{2}{|c|}{1950} & \multicolumn{2}{|c|}{1960} & \multicolumn{2}{|c|}{1970} & \multicolumn{2}{|c|}{1980} & \multicolumn{2}{|c|}{$1980^{X}$} \\
\hline & & Ne & $\%$ & No & $\%$ & No & $\%$ & No & $\%$ & No & $\%$ \\
\hline $0 \sqsubset 20$ & 20 & 12 & 35,3 & 9 & 26,5 & 7 & 20,6 & 3 & 8,8 & 13 & 19,7 \\
\hline $20 \longmapsto 40$ & 40 & 19 & 55,9 & 15 & 44,1 & 12 & 35,3 & 8 & 23,5 & 20 & 30,3 \\
\hline $40 \longmapsto 50$ & 50 & 3 & 9,9 & 10 & 29,4 & 15 & 44,1 & 15 & 44,1 & 22 & 33,3 \\
\hline $50 \longleftarrow 55$ & 55 & 0 & 0,0 & 0 & 0,0 & 0 & 0,0 & 7 & 20,6 & 10 & 15,2 \\
\hline $55 \longmapsto$ & & 0 & 0,0 & 0 & 0,0 & 0 & 0,0 & 1 & 2,9 & 1 & 1,5 \\
\hline
\end{tabular}

X Distribuição, pelas classes, dos 66 países estudados em 1980

$x$ Distribution, among the groups of the 66 countries studied only in 1980 
ladas de óbitos, o valor máximo da distância quadrática generalizada de Mahalanobis, encontrado em cada uma das quatro épocas estudadas correspondeu, sempre, a percentagens acumuladas alcançando idades maiores do que a referida por Swaroop e Uemura.

2 . Com a melhoria progressiva do nível de saúde nos países estudados, sua distribuição pelas classes, definida por Swaroop e Uemura, segundo valores da Razão de Mortalidade Proporcional, não mais possibilita diferenciação adequada, concentrando-se a grande maioria na última dessas classes.

3 . Considerando-se as vantagens que oferece, tanto em termos de valor da distância quadrática generalizada de Mahalanobis, em anos recentes, quanto da disponibilidade de fontes de dados e da possibilidade de interpretação do significado de variaçōes de uma época para outra, a Razão de Mortalidade Proporcional referente à faixa etária de 75 ou mais anos de idade deve ser adotada em substituição à proposta por Swaroop e Uemura.

4 . As variações durante um determinado período, da Razão de Mortalidade Proporcional definida pela percentagem de óbitos com 65 ou mais anos de idade, complementam as informações fornecidas pelas variaçōes dessa mesma razão baseada nos óbitos com 75 ou mais anos de idade.

5 . Tendo em conta os valores apresentados, nas quatro épocas, pelos diferentes países estudados, é conveniente reformular as classes propostas por Swaroop e Uemura, definindo-as em termos de valores da Razão de Mortalidade Proporcional referente a óbitos com 75 ou mais anos de idade, com os seguintes limites: $020,20 \quad 40,4050,50 \quad 55$ e 55 ou mais, com previsão de desdobramento futuro da última e de esvaziamento da primeira.
It may be foreseen that, with the continued advances in the level of health, the classification $0 \vdash 20$ will tend to empty out, while the classification 55レ, empty up to 1970 , will become increasingly thickly populated. It is even possible that it will be convenient to fix an upper limit for it, making it equal to $55-60$, thus creating a new classification for $60 \vdash$.

\section{CONCLUSIONS}

The results obtained and analysed, related to the countries studied in years approximating to 1950 , 1960,1970 and 1980 , lead to the formulation of the following conclusions.

1 - In the contrast between countries more or less developed, involving accumulated percentages of deaths, the maximum value of Mahalanobis's generalized quadratic distance found for each one of the periods studied always corresponded to accumulated percentages which reached higher age levels than those refered to by Swaroop and Uemura.

2 - With the progressive improvement of the health level of the countries studied, its distribution within the classifications defined by Swaroop and Uemura, according to the values of the Proportional Mortality Ratio will no longer provide adequate differentiation, as the large majority are concentrated in the last of these classifications.

3 - In the light of the advantages which it offers, as much in terms of Mahalanobis's generalized quadratic distance, in recent years, as also in the availability of sources of data and of the possibility it gives for the interpretation of the significance of variations from one period to another, the Proportional Mortality Ratio related to the age-group of 75 years of age or above ought to be adopted in substitution to that proposed by Swaroop and Uemura.

4 - The variations of the Proportional Mortality Ratio, during a particular period, as defined by the percentage of deaths at 65 years of age or above, complement the information provided by the variations in this same Ratio based on the deaths at 75 or more years of age.

5 - Taking into consideration the values presented, in the four periods, by the various countries studied, the reformulation of the classification proposed by Swaroop and Uemura becomes necessary in terms of the values of the Proportio. nal Mortality Ratio related to deaths at 75 years of age or above, with the following limits: $020,2040,4050,50 \quad 55$ and 55 or above, with the possible necessary future division of this last and the emptying out of the first. 
PAIVA, E.R. de et al. Razão de mortalidade proporcional de Swaroop e Uemura. Necessidade de revisão periódica de sua definição. Rev. Saúde públ., S. Paulo, $21: 90-107,1987$.

PAIVA, E.R. de et al. [Swaroop and Uemura's proportional mortality ratio. The need for periodic revision of the definition] Rev.Saúde públ., S.Paulo, $21: 90-107,1987$.

ABSTRACT: Using reliable data from 34 countries for the years 1950,1960,1970 and 1980 it was observed that the proportional mortality ratio for 50 years of age and above, proposed by Swaroop \& Uemura, did not provide the best discriminatory power between more and less developed countries in any of the years studied. In 1970 and 1980, the greatest discriminatory power was obtained by using the proportional mortality ratio for 75 years of age and above. The displacement of deaths to upper age groups over a certain period of time was better translated by variations in the 75 years and above than in the 50 years and above proportional mortality ratio. It is also useful to complement this information by computing the percentage of deaths at 65 years of age and above. It is suggested that the classes proposed by Swaroop \& Uemura should be reformulated using new classes based on the proportional mortality ratio for 75 years and above, with the following limits: $0\llcorner 20 ; 20\llcorner 40 ; 40 \vdash 50 ; 50 \vdash 55$ and 55 and above, with the possibility of subdividing the last group, if necessary, in the future.

UNITERMS: Health status indicators. Mortality.

\section{REFERÊNCIAS BIBLIOGRÅFICAS / REFERENCES}

1. DEMOGRAPHIC YEARBOOK: 1949-50. (United Nations) New York, 1950.

2. DEMOGRAPHIC YEARBOOK: 1951. (United Nations) New York, 1951.

3. DEMOGRAPHIC YEARBOOK: 1960. (United Nations) New York, 1960.

4. DEMOGRAPHIC YEARBOOK: 1970. (United Nations) New York, 1971.

5. DEMOGRAPHIC YEARBOOK: 1981. (United Nations) New York, 1983.

6. GOULDEN, C.H. The discriminant function. In: Goulden, C.H. Methods of statistical analysis. 2 nd ed. New York, Wiley, 1952. p. 378-93.

7. GUEDES, J.S. Contribuição para o estudo da evolução do nível de saúde do Estado de São Paulo: análise das regiões administrativas (1950-1970). São Paulo, 1972. [Tese de Doutorado - Faculdade de Saúde Pública da USP].

8. HOLLANDER, M. \& WOLFE, D.A. Nonparametric statistical methods. New York, John Wiley \& Sons, 1973.
9. KELLEY, T.L. The selection of upper and lower groups for the validation of test items. J.educ. Psychol., 30:17-24, 1939.

10. MAHALANOBIS, P.C. Apud SWAROOP, S. \& UEMURA, $K^{13}$

11. ORGANIZACIÓN MUNDIAL DE LA SALUD. Grupo de Estudio de Medicion del Nivel de Salud, Ginebra, 1955. Informe. Ginebra, 1957. (Ser.Inf. tecn., 137).

12. SOKAL, R.R. \& RHOLF, F.J. Biometry: the principles and practice of statistics in biological research. San Francisco, Freeman, 1969.

13. SWAROOP, S. \& UEMURA, K. Proportional mortality of 50 years and above: a suggested indicator of the component "health, including demographic conditions" in the measurement of levels of living. Bull. Wld Hlth Org., 17:439.81, 1957.

Recebido para publicação em 05/08/1986

Received in August $5^{\text {th }}, 1986$.

Aprovado publicação em 12/11/1986

Accepted in November $12^{\text {th }}, 1986$ 